IRA-International Journal of Management \& Social Sciences

ISSN 2455-2267; Vol.09, Issue 02 (November 2017)

Pg. no. 67-70

Institute of Research Advances

http://research-advances.org/index.php/RAJMSS

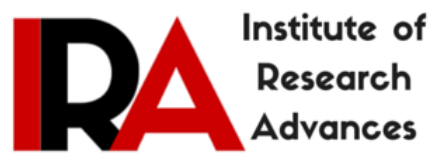

Advances

\title{
Revisiting Women Empowerment in Modern Era
}

\author{
G. Hassan Lone ${ }^{1 \#} \&$ Wakar A. Zargar ${ }^{2}$ \\ ${ }^{1}$ Ph.D Scholar, Department of Social Work, University of Kashmir, Srinagar, J\&K, India. \\ ${ }^{2}$ Assistant Professor, Department of Social Work, University of Kashmir, Srinagar, J\&K, India. \\ \#corresponding author. \\ Type of Review: Peer Reviewed. \\ DOI: http://dx.doi.org/10.21013/jmss.v9.v2.p3
}

Lone, Hassan G., Zargar, Wakar A. (2017). Revisiting Women Empowerment in Modern Era. IRA-International Journal of Management \& Social Sciences (ISSN 2455-2267), 9(2), 67-70. doi:http://dx.doi.org/10.21013/jmss.v9.n2.p3

(C) Institute of Research Advances.

\section{(cc)) BY-NC}

This work is licensed under a Creative Commons Attribution-Non Commercial 4.0 International License subject to proper citation to the publication source of the work.

Disclaimer: The scholarly papers as reviewed and published by the Institute of Research Advances (IRA) are the views and opinions of their respective authors and are not the views or opinions of the IRA. The IRA disclaims of any harm or loss caused due to the published content to any party.

Institute of Research Advances is an institutional publisher member of Publishers Inter Linking Association Inc. (PILA-CrossRef), USA. The institute is an institutional signatory to the Budapest Open Access Initiative, Hungary advocating the open access of scientific and scholarly knowledge. The Institute is a registered content provider under Open Access Initiative Protocol for Metadata Harvesting (OAI-PMH).

The journal is indexed \& included in WorldCat Discovery Service (USA), CrossRef Metadata Search (USA), WorldCat (USA), OCLC (USA), Open J-Gate (India), EZB (Germany) Scilit (Switzerland), Airiti (China), Bielefeld Academic Search Engine (BASE) of Bielefeld University, Germany, PKP Index of Simon Fraser University, Canada. 


\begin{abstract}
The growth and development of human societies has been diversely analysed across the globe. The distribution and existence of human races and the progress made thereof has put both the genders on the centre stage, where, on one hand men have been shown responsible for major part of development and on the other women as deprived and neglected. This inequality between men and women is probably a most disturbing aspect of many modern societies, though gender inequity is a global phenomenon yet, it is more prominent in developing countries and countries having nondemocratic governments. It is most tragic part of human development that major part of female population of present day civilization is facing persistent hunger and abject poverty simply because of their subjugation, marginalization \& systematic disempowerment. But of late it is the result of awakening of women's consciousness which has led women to re-define their roles from a subordinate, dependent and child bearing traditional women to the modern empowered women.
\end{abstract}

Keywords: Empowerment, Development, Modernization, Marginalizing women, Gender Inequality, Discrimination.

\title{
Introduction
}

Women empowerment is a new phrase in the vocabulary of gender literature. The phrase is used in two broad senses i.e. general and specific. In a general sense, it refers to empowering women to be self-dependent by providing them access to all those freedoms and opportunities, which they were denied in the past only because of their being a 'women'. In a specific sense, women empowerment refers to enhancing their position in the power structure of the society. The word women empowerment essentially means that the women have the power or capacity to regulate their day-to-day lives in the social, political and economic terms - a power which enables them to move from the periphery to the centre. In $21^{\text {st }}$ Century women are recognized as important stakeholders of social development. They primarily bear the responsibility to achieve goals of quality education, healthy nutrition and to raise the levels of family income. Their actions warrant an end to hunger and poverty. However at the same time one can still find institutionalized inequality not only in working of the political institutions but also in more elementary fields of social and economic life of the women such as poor health care, malnutrition or under-nutrition, over-work, unorganized and unskilled workforce, maltreatment and powerlessness. Such pathetic state of affairs is prevailing at the time when the entire human civilization feels smug about its achievements especially in the fields of science and technology in a democratic setup. Democracy as a matter of fact has been projected as an important tool to talk and gain favours about the empowerment of women. Also because of peculiar placement of women in the social, economic and political settings of society, they experience poverty, hunger and unemployment differently as compared to men.

The phenomenon that women constitute as equal partner of men in discharging their responsibility remains invisible and very surely unrecognized. What they lack is the chance to change their situation and develop their own selfsufficiency. They are systematically denied the access to the resources, which they need to fulfill their responsibility of healthcare services, educational opportunities, job training and access to freedom to use family planning choices, which primarily pertain to them. According to Kabeer (1999) empowerment entails a change in the terms on which resources are acquired as much as an increase in access to resources. No serious efforts are being done at the part of state and society to change the condition of the women. The government policies to uplift and empower woman mainly in developing countries have proved ineffective. At the initial stages it was realized that the family planning policy of China ended the gender discrimination but looking into the latest demographic patterns of Chinese society, it can be argued that women in general became the ultimate sufferers of such policies.

In case of India so far no policy framework with the objective to empower women has worked effectively. An alarming pace of female foeticide has distorted the sex ratio especially in north India. In fact genesis of modern sex determination technology has not only targeted the girl child before birth but has also spoiled the women's health conditions because of repetitive and sometimes forceful (i.e. against the will of women and also against the law of nature) abortions of female child in mother's womb. It has led to serious health complications for women especially under the conditions where they are already in the state of malnutrition. Clearly, there is an urgent need to evaluate the basic cause for the failure of public policies so that women are not taken as men's tool or burden but as equal partners in socio-economic development of humanity. Kassam (2004) has pointed out that since the 1990's women have been identified as key agents of sustainable development and women's equality and empowerment are seen as 
central to a more holistic approach towards establishing new patterns and processes of development that are sustainable. During much of the last quarter of the $20^{\text {th }}$ century and the first decade of $21^{\text {st }}$ century, development has been viewed as the panacea for all the economic ills in less developed countries. Lal (1989) believed that creation of modern infrastructure could provide a favourable environment for the economics to grow by providing better quality of life in general. But virtually in all developing countries, development has had a lopsided impact on all sections of society especially the women. Therefore the development which has widened the gap between men and women has not helped to improve women's lives, rather has had an adverse effect upon them.

\section{The Conceptual Framework}

At present whole debate on women liberation and women empowerment is by and large centered around feministic thought, and the terms such as masculinity, feminity, sexuality, maternity, subjectivity, subjugation, emancipation, etc., are being fitted in the discourse of theorization of women or women as an institution by feminist thinkers all around the globe. The emergence of women's liberationist movements portray a complex interplay of issues, values, internal and external dynamics of gender relationships, which keep on shaping and re-shaping the organic development of movements. Presently, the theory of women's liberation has been overshadowed by the radical feminism of America and Europe. According to Bhardwaj (2005) in U.S the women's movements developed from three quarters of organized women groups - New Left, Civil Rights Activists and women who had little or no experience of political thinking but were drawn to issues affecting their everyday life. The activities of all these groups were reflected in the form of agenda of radical social change. All types of feminisms-liberal, reformist, equal rights feminism, radical and socialist feminism-emerged from west and all of them have been shaping and reshaping the women's movements not only in developing countries but also in developed countries. For instance, in 1970 and 1978 seven demands such as equal pay, child care, education and job opportunities, reproductive freedom, financial and legal independence and violence against women, were worked out in British National Women's Liberation Congress as reported by Bhardwaj (2005).

The second half of $20^{\text {th }}$ century has witnessed the revolutionary transformations targeting the traditional academic philosophy pertaining to women's liberations. The theorization of women empowerment is diagonally placed between feminism at the one hand and the concrete situation of women in family and society, such as women as wife, mother, daughter, prostitute, Lesbian, as young or old as so on, on the other hand. The whole discourse of women empowerment theory originates from the percept of self consciousness and perceived oppression of women in the form of subordination to men. Before coming to various dimensions of women empowerment, it is pertinent to mention here that the concept of feminism emerged in the form of demand for equality in political processes in western societies soon after French revolution. The phenomenon of women empowerment is quite different from the concept of participation or gender. World Bank Development Report 1994 states emphatically that the aim should be to empower ordinary people to take charge of their lives, to make communities more responsible for their development and make Governments listen to their people (World Bank, 1994).

Actually, the idea of empowerment of women is drawn from the context of human rights. Human rights in this sense are broader. It includes basic needs, economic security, capacity building and skill formation and dignifies social existence, contextually, empowerment in Indian context stands for transformation of people belonging to weaker segments, and it means that the hidden meaning of empowerment is not political empowerment but social and cultural empowerment also. In other words, empowerment relates to the social transformation among women. The idea of empowerment is thus political, economic, social and cultural. It would be erroneous to think that empowerment consists only of political power, through Panchayat Raj; the women will also acquire economic and socio-cultural power. There are a large number of situations where in decisions have to be made at the family, caste, village and regional levels. The empowerment given to women would affect all these levels of life. Amartya Sen (2002) aptly relates the variety of gender inequality issues to a dichotomy present in human life between well-being and agency, which he defines as the pursuit of goals or desires that a person values and chooses to advance. According to Sen (2002) from the crude barbarity of physical violence to the complex instrumentality of health neglect, the deprivation of women is ultimately linked not only to the lower status of women, but also to the fact that women often lack the power to influence the behaviour of other members of society. This is true even today. But the society has to change its mindset. While the legislative and other measures may trigger the process, a persuasive approach through mass communication techniques together with involvement of social and family groups will have to be worked out through collective efforts of all concerned. There is widespread acceptance today that development needs to be evaluated not just in terms of economic growth but also in terms of the advancement of human capabilities, and that enhancing human well-being is not just a means but also an end in itself noted by Agarwal 
(2005). Women are the companion of men, gifted with equal mental capacities. She has the right to participate in minutest details of the activities of man, and she has the same right of freedom and liberty as man has. Men and women are equal in status, but are not identical. They are a pair-less pair being complimentary to one another, so that without one, the existence of the other cannot be conceived and therefore, it is a universal fact that anything that will impair the status of either of them will involve the equal ruin of both.

The principle of gender equality is enshrined in the Indian Constitution in its Preamble, Fundamental Rights, Fundamental Duties and Directive Principles. The constitution not only grants equality to women but also empowers the state to adopt measures to shift discrimination in favour of women. Within the framework of democratic polity, our laws, developmental policies, plans and programmes have aimed at women's advancement in almost every sphere of life.

India has the distinction of evolving one of the longest continuing civilizations in the world, which has constantly adapted itself to the changing political and socio-economic contents and specific watershed events in her history. Her family system and women has proved to be a remarkable stable unit of society which has shown great flexibility and adaptability in the phase of rapid social changes as described by Kashyap (2004). Social modernization brought about a series of major changes in the social structure. One of its strongest influences was the awakening of a woman's consciousness. With rapid economic development and the advent of the women's movement, the changing status of women received much attention around the world. The role of women began to change from the submissive, dependent and the childbearing traditional woman to the modern woman demanding for equal rights, sovereignty and independence assuming the equally heavy career responsibilities. The impact of modernization has truly affected the role of women.

\section{Conclusion}

The $21^{\text {st }}$ century is witnessing a rapid developmental change in the social sector of India. It has not only affected the agriculture sector of the country, but also put women in a position where they have a major role to play in the development of our country. Women considered less privileged in many ways hold very strong views. So it seems necessary that the women empowerment and modernization should take place in the light of their status, importance, education and health awareness. Gender inequality in India is an acknowledged and well documented fact, but its causes and its future are still a mystery. Meanwhile, we have to focus on documenting the inequalities in society for the surviving women who have less access to nutrition, education, health services and employment than men. Despite the obvious prejudices and restrictions that Indian women face, the methods and ways by which to improve their situation are not clear. While it is possible that modernization and empowerment of women will reduce the gender disparity and will show us ways of equity between the genders.

\section{References}

[1] Agarwal, P. P. (2005). Marital Voilence, Human Development and Women's Property Status in India. World Development, 33(5), 823-850.

[2] Bhardwaj, P. R. (2005). Trends in Theories of Feminism(s) and Women Empowerment. New Delhi: Anamika Publishers \& Distributors(P) Ltd.

[3] Kabeer, N. (1999). Resources, Agency, Achievements: Reflections on the Measurement of Women's Empowerment. Development and Change, 30(5), 435-464.

[4] Kashyap, L. (2004, December). The Impact of Modernization on Indian Families: The Counselling Challenge. International Journal for the Advancement of Counselling Challenge, 26(4), 341-350.

[5] Kassam, F. H. (2004). Women's empowerment in rural India. ISTR conference, Toronto Canada July, 2004. Toronto.

[6] Lal, A. N. (1989). Economics of Development and Planning. Noida: Vikas Publishing House.

[7] Sen, J. D. (2002). India: Development and Participation. Oxford University Press.

[8] World Bank. (1994). World Bank Development Report. Washington D.C: The World Bank. 